\title{
Review
}

\section{Respons Jepang dalam Gejolak Peristiwa 1965}

\author{
Wildan Sena Utama
}

Alumnus Pascasarjana Institute for History, Leiden University

Judul Buku: Peristiwa 1965: Persepsi dan Sikap Jepang

Penulis: Aiko Kurasawa

Penerbit: Penerbit Buku Kompas

Cetakan: I, 2015

Tebal: xxii + 202 halaman

ISBN: 978-979-709-972-5

Bergairahnya minat dunia akademik Barat dan Indonesia terhadap peristiwa 1965 dan kekerasan massal yang terjadi setelahnya ternyata tidak diikuti oleh perhatian yang besar dalam dunia akademik Jepang. Aiko Kurasawa dalam buku terbarunya Peristiwa 1965: Persepsi dan Sikap Jepang mempertanyakan hal ini dan menjadikan alasan ini sebagai dasar untuk menerbitkan karya terbarunya. Kurasawa di dalam pengantarnya mengatakan bahwa "minat akan topik ini begitu rendah di Jepang padahal Jepang sendiri memainkan peran sangat penting dalam memuluskan lahirnya Orde Baru" (hlm. vii). Tujuan utama dari buku ini adalah untuk menggambarkan bagaimana respons pemerintah dan masyarakat Jepang terhadap Gerakan 30 September dan menjelaskan mengapa Jepang bisa bertahan di Indonesia setelah krisis dan membantu kelahiran Orde Baru.

Karya ini menggunakan arsip-arsip Kementerian Luar Negeri Jepang yang baru dibuka. Selain itu sumber utama penulisan buku ini berasal dari arsip-arsip Kementerian Luar Negeri Inggris dan Kementerian Luar Negeri Amerika Serikat. Kurasawa lalu melengkapi sumber penulisannya dengan menggunakan koran, memoar dan wawancara terhadap orang-orang Jepang, termasuk juga Dewi Sukarno. Struktur penulisan buku ini secara garis besar dibagi dalam dua hal: pertama adalah mengenai narasi hubungan Indonesia dan Jepang sebelum peristiwa Gestok dan bagaimana respons Jepang terhadap Gestok dan hubungan Indonesia dan Jepang setelah tragedi tersebut.

Hubungan antara Indonesia dengan Jepang dibuka kembali pada awal tahun 1950an saat Jepang harus membayar ganti rugi perang kepada negara-negara yang telah dirusaknya selama Perang Dunia II. Jumlah pampasan perang yang disepakati oleh kedua belah negara sebesar 223 juta dollar atau 12 persen saja dari tuntutan pemerintah Indonesia pada awal negoisasi 
tahun 1951. Namun, menurut Kurasawa jumlah ini sangat membantu Indonesia di tahun 1958, ketika Indonesia sedang berada dalam situasi ekonomi yang cukup berat akibat naturalisasi aset-aset Belanda (hlm. 2). Di sisi lain, bagi Jepang pembayaran pampasan perang ini sangat menguntungkan karena selain jumlahnya kecil, kesepakatan ini membuka jalan bagi Jepang untuk menggantikan posisi istimewa ekonomi Belanda di Indonesia.

Dalam buku ini Kurasawa berpendapat bahwa kesepakatan pembayaran pampasan perang mempengaruhi keputusan Sukarno untuk mempercepat proses nasionalisasi perusahaan Belanda di Indonesia (hlm. 15-6). Empat hari sebelum terjadi penyitaan berskala nasional atas perusahaan-perusahaan Belanda oleh para buruh Indonesia pada 2 Desember 1957, Sukarno bertemu dengan Perdana Menteri Kishi yang berkunjung ke Indonesia untuk membicarakan angka pasti pembayaran pampasan perang. Pada persetujuan itu disepakati angka 223 juta dollar dan menurut Juanda kesepakatan ini ternyata diputuskan oleh Sukarno pribadi tanpa konsultasi dengan dirinya yang terlibat dengan masalah ini sejak awal. Sukarno, dalam pandangan Juanda, sudah demikian terobsesi dengan gagasan nasionalisasi asetaset Belanda dan berharap dapat mengambil langkah itu dengan segera menyelesaikan masalah dana pampasan perang sebagai modalnya (hlm. 15).

Pembayaran dana pampasan perang men-jamin posisi Jepang menjadi istimewa dalam ekonomi politik Indonesia. Dengan implementasi proyek pampasan perang, perusahaan Jepang diberikan akses untuk melakukan berbagai kegiatan ekonomi, di saat yang sama nyaris begitu sulit bagi negara-negara Barat melakukannya. Jepang tidak merasa cemas dengan gagasan nasionalisme ekonomi Indonesia sebab Jepang tidak mempunyai konflik kepentingan ekonomi dan juga belum secara masif menginvestasikan modalnya di Indonesia (hlm. 41). Sebaliknya pemerintah Jepang mendukung langkah nasionalis Sukarno tanpa diliputi kekhawatiran. Namun, ada satu hal yang membuat Jepang merasa was-was, yaitu perkembangan kekuatan politik Partai Komunis Indonesia (PKI) yang semakin membesar di awal tahun 1960an. Tetapi Jepang masih berkeyakinan bahwa pengaruh politik Sukarno masih mampu untuk mengontrol pengaruh PKI di Indonesia.

Citra Sukarno bagi pemerintah Jepang di akhir tahun 1950an umumnya begitu positif. Jepang menganggap Sukarno sebagai representasi pemimpin dari Dunia Ketiga dan manghargai aspirasi politik nasionalistiknya meskipun telah umum diketahui bahwa Jepang merupakan sekutu Amerika Serikat. Banyak dari politisi Jepang masih dipengaruhi oleh mentalitas Pan-Asia Timur Raya yang dipegang teguh sejak masa perang berkecamuk. Kepercayaan terhadap Sukarno bisa dilihat dari dukungan yang diberikan Jepang saat pemerintah Indonesia menghadapi PRRI di Bukittinggi tahun 1958. Kemudian, ketika Ikeda Hayato, PM Jepang pengganti Kishi Nobosuke, menjadi mediator dalam konflik ganyang Malaysia.

Akan tetapi, peristiwa simbolik yang mendorong Jepang mengalami perubahan sikap berhadapan vis à vis dengan Sukarno adalah terjadinya penculikan pada tanggal 1 Oktober 1965. Pada mulanya, Jepang tidak langsung mengambil sikap melawan Sukarno pasca G30S namun mereka cenderung mempertahankan status quo dengan berdiri di pihak pemerintah Indonesia. Para diplomat Jepang di Indonesia begitu berhati-hati menyikapi apa yang terjadi setelah peristiwa itu dan enggan untuk merintis hubungan dengan kekuatan-kekuatan baru. Namun, ketika Jepang perlahan menyadari bahwa kekuatan Sukarno mulai dikikis pelan-pelan 
oleh Angkatan Darat (AD), mereka mulai mengambil sikap yang lebih independen terhadap Sukarno.

Faksi-faksi anti-Sukarno di dalam pemerintahan Jepang makin besar suaranya dan pengaruhnya dalam mengalahkan faksifaksi yang pro-Sukarno. Mereka yang proSukarno tidak bisa memendam kekecewaan karena Sukarno dengan kukuh menolak untuk membubarkan PKI. Para politisi Jepang yang pro-Sukarno secara perlahan telah keluar dari, meminjam istilah Departemen Luar Negeri Amerika Serikat, hypnotization by Sukarno (sihir dari Sukarno). Memang masih ada faksi kecil yang belum bisa menentukan posisi dan masih tetap mendukung Sukarno. Kedutaan Jepang di Jakarta tidak utuh secara bulat anti-Sukarno sampai terbitnya Supersemar.

Setelah tragedi 1 Oktober, di Jawa dan Bali terjadi pembantaian massal terhadap anggota dan simpatisan komunis. Bahkan warga yang tidak tahu apa-apa ikut terseret arus kekerasan massal. Para diplomat dan media Jepang, menurut Kurasawa, mengetahui perihal peristiwa ini. Namun, pemerintah Jepang memilih diam terhadap fakta ini daripada mengritik secara terbuka. Tiga surat kabar Jepang, yaitu Asashi Shinbun, Yomiuri Shinbun dan Mainichi Shinbun, mempublikasikan berita mengenai kekerasan politik yang terjadi di Jawa, seperti serangan pada kantor-kantor PKI atau pembakaran rumah warga yang terafiliasi PKI. Akan tetapi, pembantaian massal yang terjadi terutama di Jawa dan Bali tidak pernah mendapatkan pemberitaan dalam skala luas oleh media-media tersebut.

Salah satu poin menarik yang diangkat oleh buku ini adalah bagaimana sikap Dewi Sukarno merespon situasi politik yang terjadi setelah 1 Oktober. Dewi, yang mempunyai pengaruh kuat dalam membantu kerjasama ekonomi antara Jepang dan Indonesia, merasa bahwa pertentangan politik yang terjadi antara AD dan Sukarno mulai menyudutkan posisi politik suaminya. Dewi yang dikenal sebagai anti-komunis ini mulai mengupayakan rekonsiliasi antara Sukarno dan jenderal-jenderal $\mathrm{AD}$ sayap kanan, khususnya Nasution. Namun, upayanya menemui jalan buntu karena Suharto telah berniat untuk mengambil alih kekuasaan dari Sukarno. Dewi sadar bahwa ia dan suaminya telah kalah dalam pertandingan ketika dalam sebuah pembicaraan tidak lama setelah keluar-nya Supersemar Suharto memberikan tiga opsi kepadanya sehubungan dengan masa depan politik Sukarno. Pertama, Sukarno bisa pergi ke luar negeri untuk beristirahat, kedua Sukarno tetap tinggal sebagai presiden simbolis atau ketiga Sukarno mengundurkan diri secara total.

Terbitnya Supersemar membuat peta politik hubungan Jepang-Indonesia berbalik seratus delapan puluh derajat. Mereka yang masih menyimpan simpati kepada Sukarno akhirnya mulai meninggalkan ilusi mereka. Menurut salah seorang mantan diplomat di Kedutaan Jepang, para staf kedutaan senang dengan keluarnya Supersemar karena mereka mengganggap bahwa Indonesia sudah lolos dari kekacauan dan ancaman komunis. Pemerintah Jepang merespons secara cepat perubahan politik dengan memberikan bantuan kepada pemerintahan baru (hlm. 179). Dengan dipukulnya PKI dan manuver Supersemar maka dampaknya juga membawa perubahan politik dalam skala global di Asia. Habisnya kekuatan komunis di Indonesia membawa pengaruh yang signifikan bagi Amerika Serikat yang sedang kesulitan menghadapi Perang Vietnam dalam rangka membendung meluasnya kekuatan komunisme di wilayah Asia Tenggara.

Menurut Kurasawa "hasil yang sangat signifikan yang membawa pengaruh sangat 
kuat dan berjangka panjang pada Jepang adalah perubahan dalam kebijakan ekonomi Indonesia" (hlm. 159). Jepang memang menikmati posisi ekonomi yang relatif nyaman di bawah pemerintah Sukarno, namun kebijakan baru ekonomi di masa Orde Baru memberikan keuntungan yang lebih dahsyat lagi bagi Jepang. Pada masa awal Orde Baru berkuasa, Jepang menjadi investor terbesar, eksportir terbesar dan negara pemberi bantuan ekonomi terbesar sehingga ekonomi Jepang mendapatkan keuntungan berkali-kali lipat.
Ekspansi ekonomi Jepang ke Asia Tenggara menjadikan Jepang muncul sebagai salah satu kekuatan ekonomi dunia. Namun, mayoritas orang Jepang, menurut Kurasawa, justru tidak tahu bahwa Jepang dapat menikmati kemakmurannya karena diawali oleh peristiwa G30S di tahun 1965. Kebijakan ekonomi pintu terbuka yang dianut Indonesia hanya dapat dimungkinkan dengan menggebuk dengan keras PKI sampai ke akar-akarnya dan menurunkan Sukarno dari kursi kepresidenannya (hlm. viii). 